\title{
Systemic project management
}

Yan Song

Lincolnshire, Illinois, USA

\section{Introduction}

Traditional project management theories and best practices focus primarily on managing the triangular constraints of time, budget and scope (framed in terms of concrete outputs). It has proven valuable and successful in helping organisations to recognise, plan and execute changes to ongoing operations in a disciplined and repeatable manner. However, as the global economy and society continue to become more knowledge based and integrated, this simple industrial model has become increasingly inadequate and, if narrowly focused and pursued, harmful. As for all branches of human knowledge, the problem did not result from knowledge itself but from a misalignment between the complexity of the phenomena and their conceptual representation or knowledge. There have been numerous attempts to extend the industrial model to include additional dimensions of project complexity (Cicmil, et al. 2009). The vast majority of such efforts still suffer from the same root cause of the original model: the mechanical conception of project management as dealing with objective facts (e.g. schedule and budget) on one hand and subjective constituencies (e.g. sponsors and users) on the other. There is a lot of literature on both aspects, but very little integrating the two into a coherent whole. In the author's experience, this lack of integration between the objective and subjective aspects of project management has become the single most critical risk of project success and the greatest advancement opportunity in the profession.

The author has spent more than a decade in managing and learning from large-scale projects in organisationally and culturally complex business environments. To cope with the vast complexities of real-life projects, he has had to 'borrow' knowledge and practices from many other fields to supplement traditional project management methods. Two such 'external' disciplines - systems thinking and leadership development - have proven particularly valuable. This case study describes a practitioner's perspective and technique for understanding and extending traditional project management to greater complexities that are typically encountered in an organisational setting. In this conception of and approach to project management, the practitioner (Self), the social environment (Organisation) and the professional responsibilities (Work) are treated as one integrated system. The dynamics of these relationships are shown to be the primary drivers of the health and success of the individual components, in contrast to the mechanical theories and practices of traditional project management. This new approach and associated set of methods is called 'systemic project management'. The case study is organised in the approximate chronological order in which the author developed, tested and expanded this new approach to project management, continuously learning and refining the methods through iterative integration of theory and practice. Part I summarises the core principles of systems thinking and leadership development as applied to project management; Part II lays out a step-by-step practice guide to aid project management professionals in defining, planning and executing a real-life project systemically; and Part III provides an example of how this method can be scaled up in a typical business organisation setting. Due to the length of this case study, only Part III is included in the current issue. Part I and II have already been published in the previous issue of this journal. 


\section{Part III: Implementation of systemic project management - a case study}

As mentioned in the introduction, systemic project management was born out of more than a decade of learning and practising project management in a complex and changing business environment. In selecting and refining the method, the author has been guided by three basic criteria: relevant (work wise), effective (organisationally) and motivating (individually) as illustrated in Figure 1. It is no accident that the method has helped the author to achieve a significant degree of success in transforming daily work experiences into impactful (organisationally) and fulfilling (personally) adventures. However, will it scale up organisationally? After consulting with, and obtaining support from, the department management where the author has worked since 2002, we began the following experiment in early 2010 .

\section{Preparing the soil}

Taking a chapter from our own book (assessing change complexity), we anticipated from the outset that there could be no easy victory. We had to confront the social complexities of the organisation and individual project managers within the group to make real progress (refer to Table 1 for definitions and interventions of social complexity). Dialogue, not standard operating procedures or process reengineering, had to be our primary means of invention. To have effective dialogues, there had to be a community setting with safety and time set aside to reflect on and learn from past experiences (above all, mistakes), both individually and collectively. Therefore, we created a Project Excellence Community of Practice with the vision 'to enhance the professional effectiveness and quality of life for individual project managers'. The community was attended by the fulltime project managers in our department and met for two hours every month to dialogue on the greatest challenges and best practices encountered in our work. As part of the kickoff for the community, the group was introduced to systemic project management in two separate workshops (two hours on core principles followed by four hours on the practice guide). Participant feedback on the workshops was very encouraging. For example, in response to the post-workshop survey question, 'what did you find most useful?' the participants answered the following:

- Applicable to future projects

- Examples and advice from industry experts

- Different project structures and better managed team

- Ladder of Inference

- Taking time focusing on learning (vs doing)

- Three levels of thinking - IQ does not equal effectiveness

- Real-life examples/templates

- Peer conversations

- Focus on people aspects of complexity.

\section{Planting the seed}

Following the work-organisation-self paradigm (Figure 1), we focused early on helping the individual project managers put their guard down and recognise the opportunities as well as challenges in our work. The so-called learned helplessness, a phenomenon popularised by the positive psychology movement (Seligman 2002), is widespread in today's workplace. Many people no longer believe in any alternative to the chaos of daily firefights. Organisations the world over unintentionally reinforce the problem by overemphasising quick fixes or 'singleloop learning', in the language of systems thinking. To break this deep-seated habit and move organisational energy in a new direction, we spent several months dialoguing as a community on the important themes in 'immunity to change' (Kegan \& Lahey 2009). For example, we helped project managers to recognise the fundamental differences between technical and 
adaptive changes in organisations and why they require different approaches for effective intervention. Most practitioners had no trouble noticing the differences but admitted that no one has ever taught them how to deal with adaptive challenges, nor were there 'official' incentives to learn them. Through the ' 4 columns exercise', we were able to demonstrate that in fact our stated organisational vision encourages and indeed demands adaptive changes but the inertia of cultural traditions still dominates our actions and acts as counter forces or immunity to such changes. To transform our performance, we must change not only the behaviours but also the 'big assumptions' or thinking behind them. Figures 7 and 8 show an example of such ' 4 columns exercise' by the group.

\begin{tabular}{|l|l|l|l|}
\hline $\begin{array}{l}\text { Espoused } \\
\text { Commitments }\end{array}$ & Doing/not doing instead & $\begin{array}{l}\text { Hidden competing } \\
\text { commitments }\end{array}$ & $\begin{array}{l}\text { Hidden big } \\
\text { assumptions }\end{array}$ \\
\hline $\begin{array}{l}\text { Be a trusted } \\
\text { pusiness partner }\end{array}$ & $\begin{array}{l}\text { Focus on short-tem } \\
\text { metrics, devaluing } \\
\text { intangibles } \\
\text { Emphasize technical } \\
\text { problem solving over more } \\
\text { complex (process and } \\
\text { strategy) issues } \\
\text { Let territorial concerns } \\
\text { trump customer interests } \\
\text { and services } \\
\text { Avoid conflicts in favor of } \\
\text { superficial agreements } \\
\text { Take unilateral positions, } \\
\text { treat own opinions as facts }\end{array}$ & $\begin{array}{l}\text { I win, you lose } \\
\text { I must be in control all } \\
\text { the time } \\
\text { I must never expose } \\
\text { embarrassment and/or } \\
\text { blame }\end{array}$ & $\begin{array}{l}\text { I have nothing to do } \\
\text { with the big mess OUT } \\
\text { THERE } \\
\text { There is NOTHING I } \\
\text { can do to clean up that }\end{array}$ \\
\hline
\end{tabular}

Figure 7. Columns exercise example — Part One: Seeing (outside-in) 


\begin{tabular}{|l|l|l|l|}
\hline $\begin{array}{l}\text { Espoused } \\
\text { Commitments }\end{array}$ & $\begin{array}{l}\text { Doing/not doing } \\
\text { commitments }\end{array}$ & $\begin{array}{l}\text { Conscious big } \\
\text { assumptions }\end{array}$ \\
\hline $\begin{array}{l}\text { Be a trusted } \\
\text { business partner }\end{array}$ & $\begin{array}{l}\text { Start Doing (1\% more): } \\
\text { Test assumptions and } \\
\text { inferences } \\
\text { Share all relevant } \\
\text { information } \\
\begin{array}{l}\text { Explain reasoning and } \\
\text { intent }\end{array}\end{array}$ & $\begin{array}{l}\text { Encourage open } \\
\text { exchange of ideas and } \\
\text { information } \\
\text { Strive for win-win } \\
\text { Respect informed and } \\
\text { free choice }\end{array}$ & $\begin{array}{l}\text { I unconsciously } \\
\text { contribute to the big } \\
\text { mess OUT THERE }\end{array}$ \\
$\begin{array}{l}\text { Focus on interests, not } \\
\text { positions } \\
\text { Stop Doing (1\% less) }\end{array}$ & $\begin{array}{l}\text { I can do SOMETHING } \\
\text { to reduce this mess and } \\
\text { make the world a better } \\
\text { place for myself and } \\
\text { others }\end{array}$ \\
\hline $\begin{array}{l}\text { Read minds, treat own } \\
\text { opinions as facts } \\
\text { Keep cards close to vest } \\
\text { My way or the highway }\end{array}$ & & \\
\hline
\end{tabular}

Figure 8. Columns exercise example — Part Two: Changing (Inside-out)

After a few rounds of such context-based dialogues, it dawned on many (not all) that their previously held cynicism about constructive change was rooted not merely in the system but also their own thinking (big assumptions).

\section{Growing the crops}

As a business organization, our management has always put a great deal of emphasis on process or efficiency improvements. Armed with insights from systems thinking, we saw many opportunities to embed new learning within existing organisational processes vs creating a separate layer on top of them. From past experiences, we knew that the new learning processes must compete with existing ones for the finite resources and visibility of running a business. The new learning processes stood very little chance for survival unless they could demonstrate immediate impact on some important aspects of the business and were also capable of continuous improvement. One of the first things we did was to enlist the help of our customers by revising our project survey. At the completion of each project, our clients and the project team are asked to fill out a survey. Our old survey focused primarily on project outcomes and singular aspects of execution. For example, we used to ask 'did the project achieve its objectives?' or 'was the communication effective?' There was nothing wrong with focusing on outcomes or specific execution skills. The only difficulty was that the answers told us very little about the root causes and what we needed to do in order to change them in a desirable direction. We did a complete redesign of the survey based on the systemic project management practice guide. The new survey is based on the behaviour and thinking required to manage projects systemically: when are we supposed to be asking what questions, how do we make decisions and do we follow through? For example, we ask everyone to assess us on a 5-point scale if the team 'anticipated the full organisational impact of the project (people and processes as well as technology) and took the necessary steps to plan, implement and support changes accordingly' or 'created a team environment where all 
members were encouraged to share their assumptions and concerns, and explain their intent and reasoning before decisions are made'

We then formed three internal teams to 'operationalise' systemic project management within the existing organisational context (Figure 9).

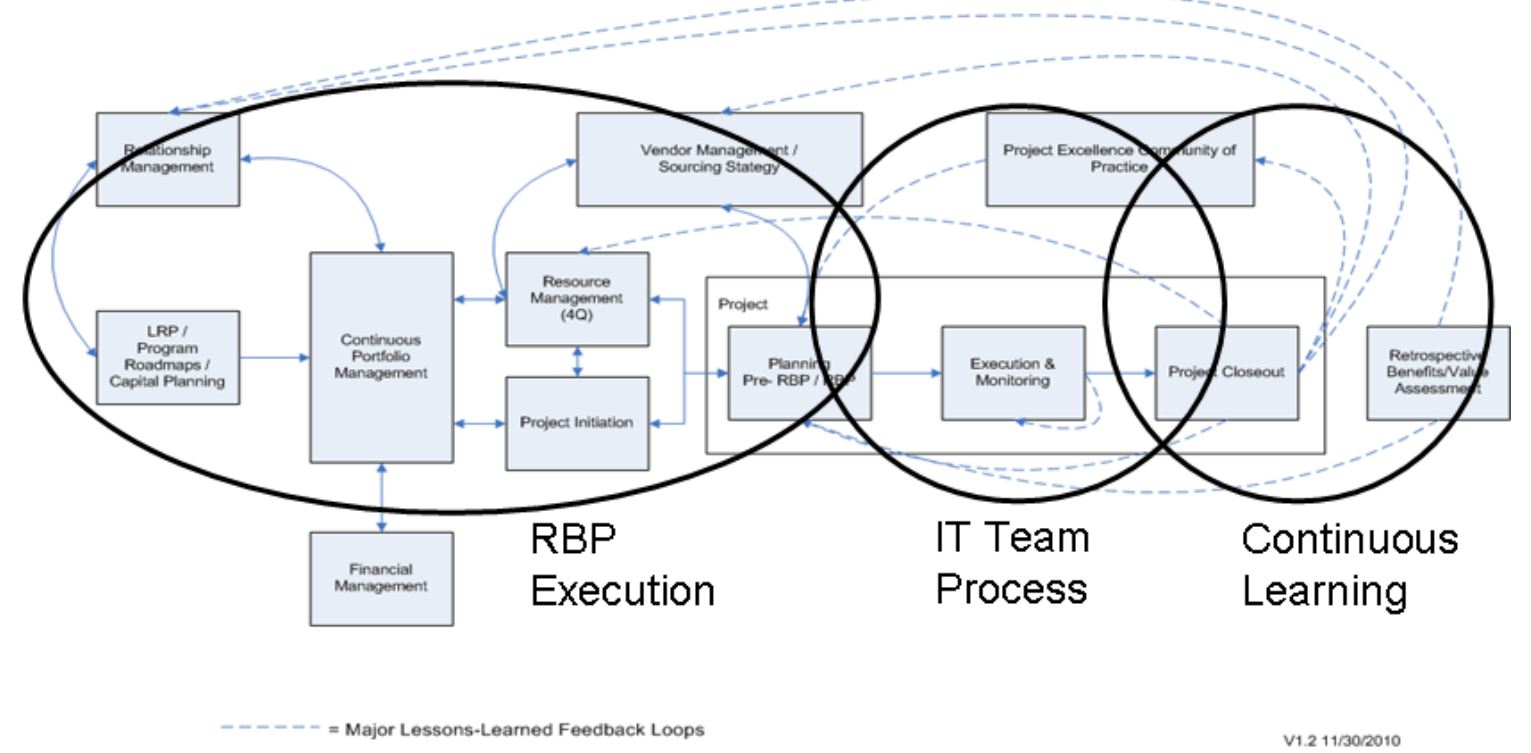

Figure 9. An example to "operationalise" systemic project management*

*For example, our current project initiation process consists of a risk-based planning (RBP) meeting in which all important stakeholders of a project are brought together to dialogue on project goals, important assumptions, deliverables, resource requirements and schedules in the context of identifying and minimising risks. It is a fine concept but has had mixed results over the years. The primary challenge has been to accomplish the ambitious planning goals within a compressed time space with stakeholders, many of whom would be meeting for the first time. Clearly, the quality of preparation and the organisational skills of the project manager before the planning session are the key drivers of a successful outcome. Systemic project management sheds valuable light into the necessary contents of such preparation and skills. For example, the why, what, who and when questions (refer to Figure 2) should be asked and answers attempted well before the stakeholders are brought together for the first time. Such early iterations help greatly to understand the diversity, dispel the misconceptions, diffuse the tensions, and build shared purpose and trust in a newly formed cross-functional team. How well a project manager prepares and facilitates such interactions is a true test of his or her mental complexity and competence as a change-maker for the organisation. Wellthought-out processes and/or templates are helpful but no guarantee for success. Informal mentorships as well as formal organisational structures maybe leveraged to optimise effectiveness.

\footnotetext{
* The author thanks Stephen Page for his support, collaboration and permission to use this diagram developed by him as the portfolio manager where this implementation has taken place.
} 


\section{Harvesting and replanting}

One year on, this journey has seen our project management function more engaged, more energetic and our reputation growing for improved focus on business values rather than merely costs and schedules. IT management support for, and willingness to invest in, learning activities have been strengthened. Increasingly, our clients trust us to assume or share project leadership roles. There is no question that systemic project management can indeed be scaled up organisationally if and when it is done systemically. We have barely scraped the surface of potential benefits. For example, we are yet to develop a plan to consistently assess and develop our project managers and align their career paths with the competency model of systemic project management. We still spend too much time chasing simplistic solutions (e.g. cloud computing to solve all IT problems) versus understanding the full complexity of the business and partnering with our clients to make a real difference. However, early evidence indicates that we are on a sustainable path for continuous improvement. The basic philosophy of systemic project management is that we cannot change ourselves or the environment overnight, but we can and should grow ourselves and influence the environment $1 \%$ at a time, in a productive and satisfying way for everyone.

\section{References}

Argyris C. \& Schon D. 1974, Theory in Practice, Jossey-Bass, San Francisco.

Argyris C. 1990, Overcoming Organizational Defenses, Allyn and Bacon, Needham Heights, MA.

Beck D. \& Cowan C. 1996, Spiral Dynamics, Blackwell Publishing, Oxford, UK.

Cicmil S., Cooke-Davies T., Crawford L. \& Richardson K. 2009, Exploring the Complexity of Projects, PMI, Newtown Square, PA.

Collins J. 2001, From Good to Great, HarperBusiness, New York, NY.

Einstein A. 1954, Ideas and Opinions, Wings Books, New York, NY.

Galilei G. 1967, Dialogue Concerning the Two Chief World Systems, 2nd Ed., University of California Press, Berkeley, CA.

Kegan R. \& Lahey L. 2009, Immunity to Change, Harvard Business School Publishing, Boston, MA.

Kuhn T. 1970, The Structure of Scientific Revolutions, 2nd and Enlarged Ed., University of Chicago Press, Chicago.

Lecioni P. 2002, The Five Dysfunctions of a Team, Jossey-Bass, San Francisco.

Oshry B. 2007, Seeing Systems, Berrett-Koehler Publishers, San Francisco.

Pellegrinelli S. 2008, Thinking and Acting as a Great Programme Manager, Palgrave MacMillan, London.

Pellerin C. 2009, How NASA Builds Teams, John Wiley \& Sons, Hoboken, NJ.

Ray M. 2004, The Highest Goal, Berrett-Koehler Publishers, San Francisco.

Scharmer O. 2007, Theory U, SoL, Cambridge, MA.

Schon D. 1983, The Reflective Practitioner, Basic Books, USA.

Schwarz R. 2002, The Skilled Facilitator, Jossey-Bass, San Francisco.

Seligman M. 2002, Authentic Happiness, The Free Press, New York, NY.

Senge P. 2006, The Fifth Discipline, Revised Ed., Doubleday, USA.

Senge P., Kleiner A., Roverts C., Ross R. \& Smith B. 1994, The Fifth Discipline Fieldbook, Doubleday, USA.

\section{About the author:}

Yan Song has more than ten years of experience managing large-scale and complex business projects at several Fortune 500 companies, including his current employer, Abbott Laboratories. He has a successful track record of applying the principles and methodologies of organisational learning and systems thinking to maximise the returns of business investments in people, processes and technology. Yan received his PhD in physical chemistry from the University of Wales in 1989.

Email: yan.song@abbott.com 